\title{
Charles Darwin as a Celebrity
}

\section{Citation}

Browne, Janet. 2003. Charles Darwin as a Celebrity. Science in Context 16, no. 1: 175-194.

\section{Published Version}

doi:10.1017/S0269889703000772

\section{Permanent link}

http://nrs.harvard.edu/urn-3:HUL.InstRepos:3345923

\section{Terms of Use}

This article was downloaded from Harvard University's DASH repository, and is made available under the terms and conditions applicable to Other Posted Material, as set forth at http:// nrs.harvard.edu/urn-3:HUL.InstRepos:dash.current.terms-of-use\#LAA

\section{Share Your Story}

The Harvard community has made this article openly available.

Please share how this access benefits you. Submit a story.

\section{Accessibility}




\title{
Charles Darwin as a Celebrity
}

\author{
Janet Browne
}

Wellcome Trust Centre for the History of Medicine at UCL

\section{Argument}

Several recent works in sociology examine the manufacture of public identities through the notion of celebrity. This paper explores the imagery of Charles Darwin as a nineteenthcentury scientific celebrity by comparing the public character deliberately manufactured by Darwin and his friends with images constructed by the public as represented here by caricatures in humorous magazines of the era. It is argued that Darwin's outward persona drew on a subtle tension between public and private. The boundaries between public and private were blurred by the ritual of Darwin "showing" himself in the flesh, either at home to visitors or, more rarely, on public occasions. The reputation for privacy and illness that he built up added materially to this public face. By contrast, caricatures tended to depict him as an ape. These apish representations played a significant role in associating Darwin, rather than any other thinker, with the notion of evolution, and in creating an alternative public persona over which he had no direct control.

Looking back over the twentieth century it is easy to see how extensively the modern era has been permeated by the notion of celebrity. From the birth of the Hollywood movie-star system in the 1920s and 1930s to the media personalities, sporting icons, and self-consciously manufactured rock groups of more recent decades, it is clear that the structures of fame have become ubiquitous. The analytic literature dealing with these concerns is impressively large, ranging from studies of "greatness" in its traditional formulations of virtue, genius, or character, to self-representation and the culture of consumption (Braudy 1986; Goffman 1990; Schickel 1985; Gledhill 1991; Marshall 1997). ${ }^{1}$ Sub-genres of sociology focus on famous last words, celebrity sportsmen, the cultish veneration of public figures, or the narrative principles of the journey inside the "real lives" of celebrities. Even the most academic of publishing houses will favor biographies of the famous over those of the obscure. All over Britain commemorative plaques are fixed to houses where noted individuals once lived. It is

\footnotetext{
${ }^{1}$ With regard to the history of fame, see Baker 1996; Briggs 1991; Quennell 1974; Donoghue 1996; and Casteras and Peterson 1994. Something of the life of the famous is conveyed in Healey 1986.
} 
a commonplace to say that every cultural grouping makes the celebrities for which it yearns.

What is the historian of science to make of this? Few scientists hit the mass media in quite the same way. Yet as Alan Friedman and Carol Donley made plain in their innovative study Einstein as Myth and Muse, celebrity culture is a choice area in which to think about the manufacture of scientific identities and to examine the relationships between fame and claims to fame (Friedman and Donley 1985). Some of the comfortable assumptions about popular culture can be dismissed straight away. Celebrated individuals invariably work hard for their position. Every celebrity has possessed, to various degrees, ambition, action, achievement, and talent, and these are surely qualities that also drive scientists and creative artists. James Monaco therefore argues too smoothly that "manufactured" celebrity has, in the later twentieth century, entirely superseded earlier ideologies of the hero - the hero in whom personal qualities were felt (at least in part) to match up to his or her public position. In the process, Monaco claims, notions of innate talent or creative genius have long since disappeared (Monaco 1978; Goode 1978; Sudjic 1989). ${ }^{2}$ Nevertheless, he is right to draw attention to the manner in which the combined desires of the audience and the developing media have directed the process of acclaim. Public response is an issue that involves more than talent alone. Much the same question arises in the field of scientific biography. Since most biographical writing about the famous nowadays concentrates on private life, and the tensions between creativity and the marketplace, where might the content and public evaluation of scientific theories fit in? ${ }^{3}$

Charles Gamson, on the other hand, investigates exactly the fictions of celebrity imagery. He values these representations in the manner of Andy Warhol for their insight into the cultural heart of a nation (Gamson 1994). ${ }^{4}$ Elsewhere in the literature, David Giles focuses on the unstable psychology of stardom, especially the celebrity's occasional, and sometimes stupendous, failure to distinguish between real life and public image (Giles 2000). Interestingly, he also addresses the public's reciprocal desire to merge in their idol fiction with reality, a theme that was explored by Jane Gaines in her study of Jacqueline Onassis (Gaines 1989 and 1991). ${ }^{5}$ Such dissolving boundaries between public and private can in part be tracked in modern celebrity magazines - the tabloid phenomenon, in which the public's wish to participate in the private lives of modern celebrities is fed by photographs of their homes and families, lovers, and rehabilitation clinics. Clearly these trends have been fostered in various ways by the development of photography as a medium, and indeed on the way that photography during the nineteenth century drew special attention to the face

\footnotetext{
${ }^{2}$ Valuable early insight can be gleaned from Bernays 1928.

${ }^{3}$ For the place of virtue and virtue ethics in biography, see Soderqvist 2000.

${ }^{4}$ This contains a helpful bibliography.

${ }^{5}$ Contested ownership of a photographic image brings many of these issues into the limelight, as discussed in Edelman 1979.
} 
(Heyert 1979; Maddow 1977; Tonkonow and Trachtenbert 1995; see esp., Jordanova 2000a; Hamilton and Hargreaves 2001). Fame is associated with the photographed face in a manner that helped invent the modern celebrity. Other scholars dissect the way postmodern audiences refuse to allow themselves to be manipulated by the media machine. While science presents a rather different set of circumstances because of its claims to disclose truths in nature, it should be possible for historians to use some of these ideas as a guide to the construction of scientific celebrities, the feted intellectual pundits of another era.

These points of view impinge on Darwin as a global celebrity, both past and present, alive or dead. Here I confine myself to Britain during Darwin's lifetime, although there is much that could be said about the manufacture of Darwinian images in different national contexts in tandem with the consolidation of successive cultural movements after his death in 1882 (e.g., La Vergata 1985). One has only to think of the rallying spirit of the 1909 anniversary celebrations of the Origin of Species, presented at a time when Darwinism was badly shaken; or Betty Smocovitis' study of the 1959 Darwin centennial celebrations organized in the United States by leading evolutionary biologists who sought to advertise the integration of Darwinian selection theory with genetics and population ecology in the new evolutionary synthesis (Smocovitis 1999; see also Bowler 1988). ${ }^{6}$ Jim Moore's study of Darwin's burial in Westminster Abbey provides an essential starting point for this form of scientific propaganda, reinforced by Hannah Gay's account of Spencer's failure to achieve any equivalent accolade (Moore 1982; Gay 1998). ${ }^{7}$ Illuminating historical work on autobiographies, commemorations, discipline formation, boundary debates, anniversaries, and portraiture bears on the same general issues (Am and Elliott 1999; Yeo 1988). ${ }^{8}$ The authors in Richard Yeo's and Michael Shortland's Telling Lives in Science, and Patricia Fara, in her studies of Newton, have done much to press into new areas (Shortland and Yeo 1996, see esp. Cantor, 171-193; Fara 2000a, 2000b, and 2002). Certainly in Darwin's case, his death allowed a relatively free hand to his image-makers and disciples (Moore 1994). ${ }^{9}$ Papers still largely unexplored in the Darwin archive at Cambridge University Library would provide researchers with resources for a study of some of the negotiating processes involved in bringing

\footnotetext{
${ }^{6}$ I thank Marsha Richmond for access to her work on the 1909 commemoration.

${ }^{7}$ Background information can be found in Hall 1966. See also Avner 2000; Outram 1978; and Jordanova 2000.

${ }^{8}$ There is a large body of relevant literature on the history of portraiture. Scientific portraiture is explored in Jordanova 2000a; Fara 1998 and 1997. See also Keynes 1994 and McLachlan 1983. A full iconography of Charles Darwin is still lacking but a summary list has been prepared by J. Browne, A. Desmond and J. Moore for the Darwin entry in New Dictionary of Biography (Oxford: Oxford University Press) forthcoming.

${ }^{9}$ L. Miller (2000) gives a literary perspective on legend-building. For the control that descendents and relatives sometimes tried to exert on the reputation of an eminent member of the family, see (in part) Browne 1978 and 1981.
} 
propagandist "personae" to the fore, personae that are familiar analytical entities in literary studies and the fine arts. ${ }^{10}$

However, the last twenty years of Darwin's life allow questions of a more autobiographical nature in so far as he may have participated in the construction of his public identity. Moreover, the time-span 1860 to 1880 invites speculation about those aspects of the Victorian scientific context involved in the distribution and popularization of evolutionary theory. ${ }^{11}$

There is a wealth of material from which to choose. Darwin's later life displayed many of the attributes of modern celebrity. He had photographs mass-produced to send out to correspondents and supplied biographical entries for compendia of "men of the times." He signed autographs and answered fan mail. He gave away cheap copies of his books as souvenirs, collected poems and popular songs composed about him, and received celebratory addresses on his birthday. He was presented to the Prince of Wales, a longstanding (and continuing) tradition in the lives of the privileged classes in Britain. There were forgeries of his signature. There were art works commissioned by various scientific societies, several of these being reproduced for public edification in the Illustrated London News. All these phenomena were culturally specific. If Goethe or Humboldt were considered in the same light, the situation would be equally bound by context. Darwin never, for example, took his breakfast in public as Humboldt did, his every mouthful watched by an admiring audience.

Two themes emerge. First, an increasing number of individuals made personal visits to Darwin's home in order to sit at his feet, visits that can be considered as the Victorian equivalent of a celebrity interview. Second, a flood of caricatures relating to Darwin were published, the visual equivalent of today's media attention. These two elements, public appearances and pictures, are key features of any modern analysis of celebrity culture.

\section{Public Appearances}

Counter-intuitive though it may be, it is important to emphasize that after the Origin of Species was published in 1859 Darwin did not become a timid rural recluse. During the 1860s and 1870s he made several notable public appearances in London and Cambridge, appeared on the podium at the Linnean Society to deliver papers about

\footnotetext{
${ }^{10}$ Several of these themes are emerging as publication of Darwin's correspondence continues (see Burkhardt and Smith et al. 1985-2001). A synopsis of the full correspondence is given in Burkhardt and Smith et al. 1994, which is reviewed in Moore 1985. Letters from Darwin's acquaintances written after his death with a view to recording his memory, and collected by his sons, are in DAR 112, Darwin Archive, Cambridge University Library.

${ }^{11}$ I am using the term "popularization" loosely here, to convey the percolation of evolutionary theory through public culture rather than the "reception" of Darwinism (see Cooter and Pumfrey 1940).
} 
his botanical researches, and often entertained guests at his home in Kent. His wife's diary records a large number of people coming in and out of Down House. In one typical week in September 1868, she listed eight people other than family members as guests in the house, one more at her sister's home down the road, four neighbors coming to join them all at a dinner party, and two late arrivals on Tuesday (Emma Darwin's Diary). The interplay between public and private in his life deserves much closer study. For it is here, in the ritual of "showing himself," that Darwin acknowledged his status as an intellectual. As time went by, he took on some of the responsibilities of a celebrity, opening up his home to visiting scientific societies almost as if he were a national monument and feeling obliged to invite noteworthy figures like Ludwig Buchner to lunch. Yet he did not like public appearances unless they were structured to his advantage. He avoided occasions on which he might be forced to answer questions spontaneously, or in front of a crowd, for he was unwilling to be caught unprepared. He was usually ill beforehand and afterwards, a useful strategic device even though probably sincerely felt (Browne 1998; see also Colp 1977). As it happened these personal inclinations meshed perfectly with a marketbased ideology of exclusivity. Such carefully managed appearances would in other realms be regarded as an effective technique for publicity management: value goes with scarcity. It worked materially to Darwin's advantage to be regarded as ill and reclusive.

Even so, Darwin did not deliberately turn himself into a rare and valuable commodity. Privacy was central to his sense of himself. By avoiding public appearances in the debates over the Origin of Species, he made his preferred position clear. This is not to say that he withdrew from participating in the controversy. On the contrary, as his collected correspondence shows, he worked ceaselessly behind the scenes to steer the direction of debate. The generally accepted view about Darwin's purported withdrawal in fact needs considerable updating. In actuality, he exercised a strenuous, sometimes ruthless discipline over the Darwinian uproar but he did it quietly by letters and private influence. While not part of the current paper, it might be suggested that Darwin's deliberately detached stance was surely an important contributory factor in the development of the Victorian scientific "persona" as an impartial figure, distant from the fray, dedicated only to the evidence of natural phenomena.

As soon as he was famous, this reputation for privacy added a certain mystique. ${ }^{12}$ Unlike modern celebrities, Darwin never gave interviews except when he supplied biographical details for various dictionaries or invited people to his home. Occasionally he answered inquiries about the genesis of his theories, his religious views, or his social opinions; he assumed these letters or conversations were not for publication unless a direct request were made. Nor was his autobiography, written

\footnotetext{
${ }^{12}$ Public and private are discussed in Margolis 1995.
} 
from 1876, intended for publication (Neve 2002). ${ }^{13}$ By contrast, Alfred Russel Wallace gave at least four newspaper and magazine interviews in old age. Thomas Henry Huxley had a well-known weakness for a good media splash and Joseph Hooker of Kew Gardens and John Lubbock enjoyed spinning public stories about Darwin in commemorative speeches after his death. In this, Darwin's friends revealed tacit knowledge of the gradations of intimacy permissible in Victorian Britain. For Darwin was no celebrity at home. His family and his household staff knew him as a father, brother, husband, invalid, and master. Close friends like Hooker, Huxley, Lubbock, Charles Lyell, and a number of others, not necessarily scientific, saw him as a man and colleague first. Other men and women knew him well but not closely. At the end of the scale, a large number of people barely knew him at all, even though they might correspond with him or read his books. The aura of celebrity seemingly increased as personal intimacy receded. Indeed, distance would appear to be an essential part of the definition of celebrity.

When combined with Darwin's wish to be private, this gave his friends a privileged position in the eyes of the external world. Huxley's status as an authoritative mouthpiece for the new biology, for instance, was enhanced. Without any need to advertise the advantage, he could capitalize on the fact that he discussed leading themes in evolutionary theory with Darwin himself. Huxley often acted as an intermediary between Darwin and his readers, sometimes negotiating meetings, other times protecting his friend's privacy (Desmond 1994/97).

For those others who did manage to encounter Darwin on a personal basis in the post-Origin period, the experience could carry a sub-religious tone. When Ernst Haeckel visited Darwin in 1866, having arranged an introduction through Huxley and sending along a copy of his most recent book, he treated it like a religious pilgrimage. Darwin planned the occasion with military precision. He was careful to warn his guest well in advance that he would not be available for scientific conversation. "My health is a good deal improved but I find it impossible to converse with any one for more than a quarter or half an hour at a time. So you must forgive me for often leaving you" (Haeckel 1866). ${ }^{14}$ Cautiously, he invited John Lubbock for dinner to relieve the social pressure; he requested Huxley to update Haeckel with the progress of biology before putting him on the train to Down House and asked Lubbock to take Haeckel back with him for the night. The event hardly justified so many precautions. Even though Darwin could not decipher the other man's heavy accent, and Haeckel's voice boomed out as if he were on a yacht, shouting against the winds and waves, their mutual interests carried them safely through. "I have seldom seen a more pleasant, cordial \& frank man," Darwin reported with relief afterwards (Burkhardt and Smith 1994, item 5261, Nov.-Dec. 1866). He and Emma came to

\footnotetext{
${ }^{13}$ See also Highfield and Carter 1933, in which Einstein is shown presenting himself to the public as a man who lived only for his science. A useful source from the literature on autobiography is Conway 1998. The rise of autobiographical writing in the nineteenth century is discussed in Machann 1994 and Peterson 1986.

${ }^{14}$ For the visit, see Burkhardt and Smith 1994, item 5248, 19 October 1866.
} 
regard Haeckel's hero-worship with amused delight, "a great good-natured boy," they called him.

Haeckel said that he felt he had been touched by greatness. His meeting with Darwin was important to him; and he waxed lyrical about the great man in his biological lectures at Jena. Young Frank Balfour, the Cambridge embryologist, was different in that he was a friend of one of Darwin's sons, and was personally invited by Darwin to spend a weekend at Down, hospitality that was reciprocated by Balfour offering Darwin lunch in his college rooms in 1880. Balfour's zoological reputation was embellished by this personal contact with Darwin.

Anton Dohrn of the newly established Naples Zoological Station also longed to see Darwin during a trip to England in 1867 but was afraid to ask. After several years of polite zoological correspondence, Darwin invited him for lunch in 1870. Dohrn described it as a cherished memory, although noting that Darwin did not look nearly as ill as he expected (Groeben 1982, 98-9). Dohrn's time for private discussion at Down House was rationed to one hour. Here Darwin's celebrity blended seamlessly into his well-known (and useful) reputation for ill health - his time was limited, his strength was weak, his prestige was high. As a result, Dohrn felt he was meeting royalty. From this time on, Dohrn assiduously used Darwin's celebrity to endorse the scientific work and help finance the Zoological Station at Naples (see Groeben 1982, n. 24).

While royalty evidently falls into a different cultural category from celebrity - in Britain being simultaneously hereditarian, ceremonial, and somehow more intimate and more aloof in its display than the lives of media personalities - something of the same sense of royalty came through in 1880 , when Darwin agreed to receive in his house fifty visitors from a local scientific society. He intended to deliver a brief geological speech to the group, but gave this up in favor of a handshake with each of them before providing claret cup and biscuits in the drawing room, apparently realizing that personal contact was what was desired, some form of individuated attention, however fleeting or structured. The motif was repeated when he attended the International Medical Congress held in London in August 1881. At the Congress's opening conversazione he seems to have upstaged most of the other dignitaries, shaking hands like royalty with scores of eminent foreign visitors, most of whom he knew through correspondence and reviews, finding a polite word to say to each. Huxley was sufficiently amused by the fuss that he too asked to be introduced to Darwin, bowing horizontally over his old friend's hand with an elaborate flourish. The chaff between them could not disguise Darwin's star quality. Conversely, some visitors to Darwin's home felt as if they were participating in history, as evidenced by the solemn thoughts that occupied Claas Hubrecht's mind in 1879 on the train from Charing Cross to Orpington. Hubrecht said he would not have been surprised to see Shakespeare en route.

If one were writing about commercial products instead of people and ideas, these occasions would fit neatly into a model of celebrity product endorsement. Many of 
the individuals who met Darwin recorded the occasion in his or her memoirs although it should be remembered that these individuals for the most part came from the middling and upper strata of society. There is a silence at the core of his personal interactions with other kinds of people, say with gardeners. Moreover, there seems to have been something special about an actual meeting, a "seeing in the flesh," or "witnessing," that ultimately hinged on affirming that the celebrity really did exist beyond the text. Maybe through these means the viewer came to recognize himself or herself also as part of living, moving history. As Steven Shapin suggests in another context, perhaps people needed to see the "truth" written on Darwin's body or reflected in his eyes (Shapin 1994). The selected younger sons of the evolutionary movement, like Dohrn or Haeckel, were certainly given an imprimatur. Even eminent Victorians such as Tennyson and Gladstone mentioned meeting Darwin, however briefly. ${ }^{15}$ Other less favored supplicants made do with an autograph or a photographic carte-de-visite. Often the letter itself became a memento of emotional or later commercial value.

Darwin guarded his name closely towards the end. He was angry with Frances Power Cobbe for publishing a private letter of his, in which he criticized the English judiciary, and broke off relations with her. He withdrew his endorsement from the letterhead of a freethinking American journal, the Index, when its political line became discomforting to him. He refused Edward Aveling's request to dedicate Student's Darwin (1881) to him (Feuer 1975; Colp 1982).

Crowd events were probably more significant in the witnessing sense. When Darwin went to Cambridge in 1875 to receive an Honorary LLD from the university, students crammed the gallery of the Senate House to chant "Monkey, monkey," before dangling a stuffed monkey over the balcony. The students were there so that they could say they had been there. It was the sense of occasion that fired them. Other times Darwin was caught by surprise. In 1881 he went to London to hear John Burdon Sanderson speak on the movements of plants. Entering the crowded lecture hall to take his seat, a burst of clapping perplexed him sufficiently to look round to see if the speaker had arrived. But the audience was applauding him (Litchfield 1904, $2,315)$. Here, and elsewhere, he fell into the divide between public and private. He was astonished at being recognized.

This brings us back to the idea of public character. Darwin's renown naturally rested on the Origin of Species, a book suffused with autobiographical structures mostly developed while writing his Journal of Researches. The point is not trivial. The Origin was highly personalized, one long invitation to believe, to trust in its author, and to accept his findings however contentious or counter-intuitive they might seem. This personalized style allowed Darwin to demonstrate his respectability, his responsible investigation of the facts, his commitment to verification, his acquaintance with experts, his claim to ownership of the theory. He could differentiate himself from the

\footnotetext{
${ }^{15}$ Described in Browne 2002.
} 
anonymous evolutionary tract Vestiges of the Natural History of Creation authored by Robert Chambers (Secord 2001) and from Alfred Russel Wallace. Even without knowing him personally, his readers could experience an impression of intimacy what has been called intimacy at a distance. Subsequent books written in the same personal style reinforced the impression. ${ }^{16}$

By placing individuality, intimacy, and privacy at the core of his public persona, Darwin stood on the threshold of a celebrity template that, in the twenty-first century, would seemingly end up with more interest being displayed in the person than in the achievement.

\section{Public Image}

Caricatures, on the other hand, revealed the manner in which members of the Victorian public perceived him. They vividly presented the voice of the people. Indeed it is a little surprising that apart from Martin Rudwick's and Jim Paradis' studies of Victorian satire (Rudwick 1975 and 1976; Paradis 1997; Browne 1992), other work on medical lampoons (Weber 1936; Sykes 1995; Porter 2001) and Patricia Fara's work on Joseph Banks (Fara 1997), caricatures have not yet featured much in the history of science. A humorous cartoon, after all, makes new ideas, or the problems and inconsistencies inherent in new ideas, obvious by deflating pomposity and airing fears; and caricature was a favored form of satirical comment in eighteenth- and nineteenth-century Europe, intimately tied up with the social and political upheavals of the era. Citizens created a public space for themselves where they could participate in contemporary events that would otherwise be closed to them; and popular humor was a powerful instrument of subversion. M. L. Townsend's work on humor, censorship, and the limits of repression in nineteenth-century Berlin and Judith Weschler's study of political caricature in nineteenth-century Paris amply illustrate the point (Townsend 1992; Weschler 1982; more generally, see George 1959; Donald 1996; Altick 1997). ${ }^{17}$

There is a minor distinction to be made between caricature and cartoon. While caricatures take their origin from conventional portrait studies - studies of character - and exaggerate character traits for effect, as in Hogarth, Gillray, or Rowlandson's work, and contributed to pointed satirical traditions in Britain and France, cartoons as we now know them emerged as a trend in 1843 with drawings in Punch, altogether a milder, more gently humorous form of topical comment. Marked changes in printing and illustrative technologies, diversification of social structure, and the proliferation of illustrated books and serials in the middle years of the nineteenth century, meant that there was a real expansion in the audiences in Britain receptive to this kind of topical reference. In the hands of John Doyle ("HB") and his son

\footnotetext{
${ }^{16}$ First discussed in Darwin 1887, vol. 1, pp. 155; also in Browne 2002, 53-63.

${ }^{17}$ The roots of celebrity caricature are explored in Reeves 1998.
} 
Richard Doyle, John Leech, then John Tenniel, Edward Linley Samborne, Ernest Griset, and Charles Keene, British cartoons came to embody British middle-class social comment on a wide range of issues (Price 1957; Harvey 1970).

The Punch cartoonists knew their audience: they presented material in terms that clearly identified the issues at stake, having little need for elaborate decoding. Nor did they perceive any necessity to resolve conflict in the themes presented. Sometimes a line or two of text made the meaning certain. The cartoons were always culturespecific and it is worth noting that the individuals they portray could not control the subject matter. The pictures, and their messages, had a life and impetus of their own, and as such indicate the artists' understanding of the likely audience response to a figure like Darwin. In short, they signal the moment at which Darwin's science became public property. ${ }^{18}$

Irony and satire were of course much used by Victorians to express their anxieties about science. And of course evolution - stretching from Robert Chambers'Vestiges through to the "new woman" debates of the late nineteenth century - possessed humorous potential that was not directed at Darwin alone. In the era of Punch (founded 1841), Figaro (f. 1870), the Comic Times (f. 1850), and Fun (f. 1861), the evolutionary relationship between humans and animals allowed much play with the idea of transmutation. A common theme was to represent politicians as snakes in the grass or toadies. Cartoons also explored explosions of high feeling involving apes, Africans, slavery, racism, and human identity.

Victorian artists grabbed their chance. "Am I a Man and a Brother?" asked a gorilla in the May 1861 number of Punch, simultaneously echoing evolutionary theory, Paul Du Chaillu's sudden appearance on the scientific scene with his traveler's tales and gorilla skins, and the anti-slavery campaigns of the 1830s (fig. 1). ${ }^{19}$
Am I satyr or man?
Pray tell me who can,
And settle my place in the scale.
A man in ape's shape,
An anthropoid ape,
Or monkey deprived of his tail?

Irresistibly, the Punch cartoonists indicated that apes were more intelligent than humans were because they knew when to keep silent. A Mr. Gorilla, dressed in evening clothes, was pictured arriving as a guest at a high-society party. This was pure Punch showmanship, linking obscure trivia with grave scientific discussion (Paradis 1997, 158). Linguistic satire played off the Irish political question against long-

\footnotetext{
${ }^{18}$ Documented in written form in Ellegard 1990. For reader response theory, see Eco 1979. The magazine Punch was particularly noted for its exhaustive chronicling of Benjamin Disraeli's ascendency. Representations of Darwin, and of science in general, form only a very small proportion of the visual imagery in the magazine.

${ }^{19}$ Punch 40:206, 18 May 1861. For Du Chaillu, see McCook 1996.
} 


\section{MONKEYANA.}

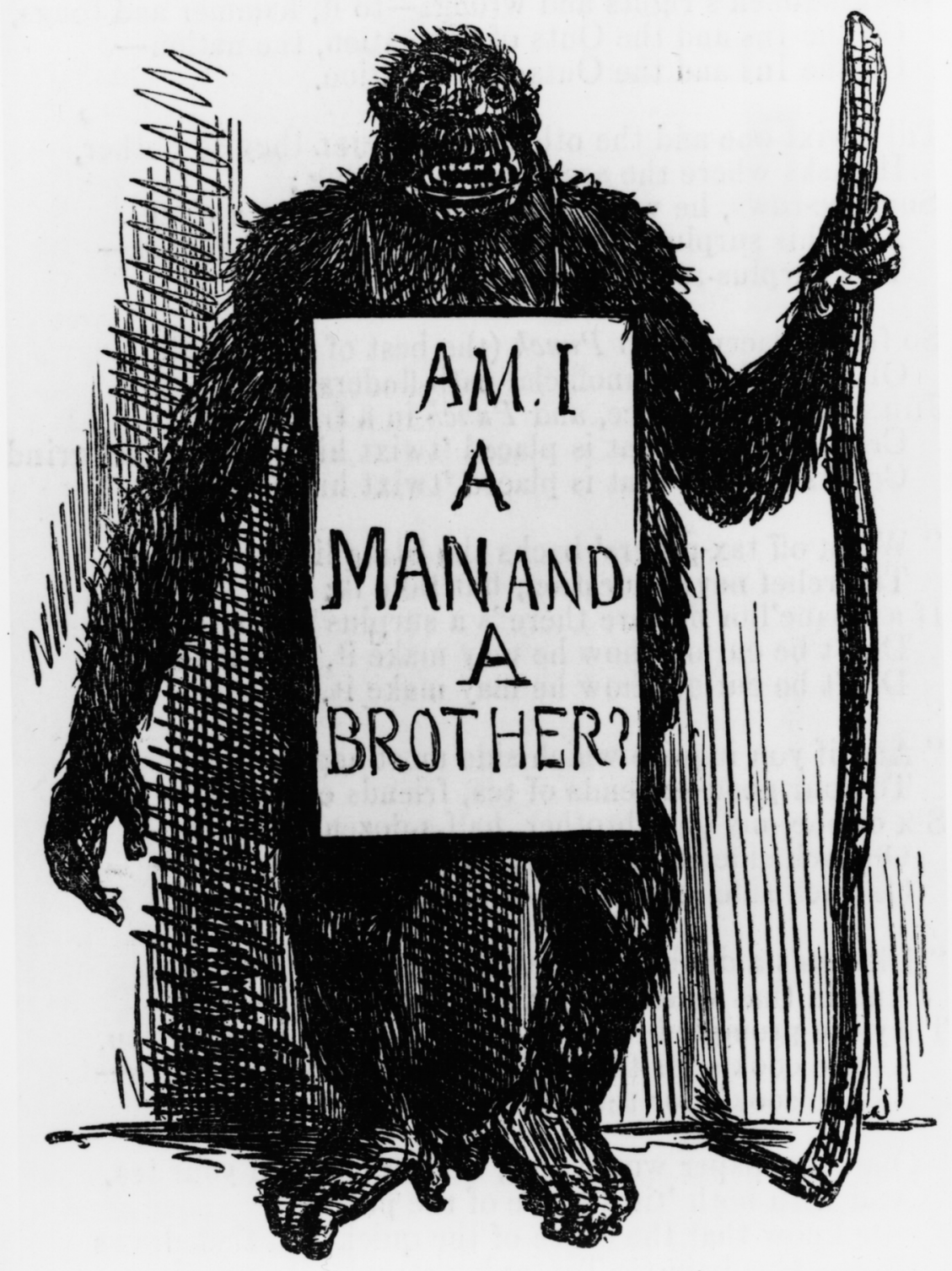

Fig. 1. From Punch, or the London Charivari, 18 May 1861. This cartoon juxtaposes topical mid-century themes of Darwin's Origin of Species, anti-slavery campaigns, and Paul Du Chaillu's sensational accounts of gorilla hunting. Unsigned wood engraving. Courtesy of the Wellcome Library London. 
running appearances from Mr. O'Rilla. Appreciative of the public taste for apes, Punch dedicated its 1861 Christmas Annual to the gorilla, and showed Mr. Punch playing leapfrog with his alter ego for the year. Another set of cartoons by Charles Bennett, independently published in 1863, displayed transformations from inert objects like a leg of mutton into humans (fig. 2). ${ }^{20}$ These cartoons not only conveyed the central point about human ancestry lying at the nub of Darwin's theory but also created an alternative form of discussion. They developed their own vernacular. This idiomatic characterization of high science is ripe for study by historians of popular scientific culture.

With the publication of the Descent of Man in 1871 and the Expression of the Emotions in 1872, Darwin himself began to appear in the cartoons, usually as the ape. His personal facial attributes, such as his beard, the great dome of his skull, and the prominent eyebrows, were simultaneously made familiar to the public through linedrawings taken from portrait photographs and reproduced in the Illustrated London News (1871, 58:244), Harper's Weekly Magazine (1871, 308) and elsewhere. These facial features are heavily emphasized in every caricature around the time of the Descent of Man. At one level, these draw on the acknowledged iconography of intellectuality; any caricature of the day would have emphasized stereotypical attributes of knowledge, which could include baldness, white hair, spectacles, an absent-minded air, a blackboard, and so on. ${ }^{21}$

Yet an element of personal recognition was involved. Darwin's facial hair was a gift for any caricaturist depicting evolutionary issues (fig. 3). His general hairiness could easily be turned into the animal fur of anthropoid apes (fig. 4). These pictures of Darwin-as-ape readily identified him as the author of the Descent of Man. Few other scientists would have been so recognizable in the public prints of the day. Neither Huxley nor Wallace appeared in caricature as frequently as Darwin. The personification of Darwin-as-ape identified him - and him alone - with evolution (however widely or narrowly it was defined). His public image here became embedded in a representation of the scientific theory he was presenting.

These visual statements propelled the idea of evolution out of the arcane realms of learned societies into the ordinary world of humor, newspapers, and demotic literature. Without Mr. Punch's monkeys and gorillas, the full implications of Darwin's densely packed proposals would have taken much longer to sink in. Because of this, we should perhaps view mass-produced caricatures in socially positive terms, as contributing to a greater group identity and perpetuating a shared ideology, especially in an era when science was taking on a separate identity.

Where does this leave us in regard to the construction of Darwin's public persona? To a certain extent Darwin paid attention to his self-fashioning, in the style of

\footnotetext{
${ }^{20}$ Republished in album form in Bennett 1872. The evolutionary cartoons run under the sub-title, "The Origin of Species dedicated by natural selection to Charles Darwin."

${ }^{21}$ Discussed in part in Browne 1998.
} 


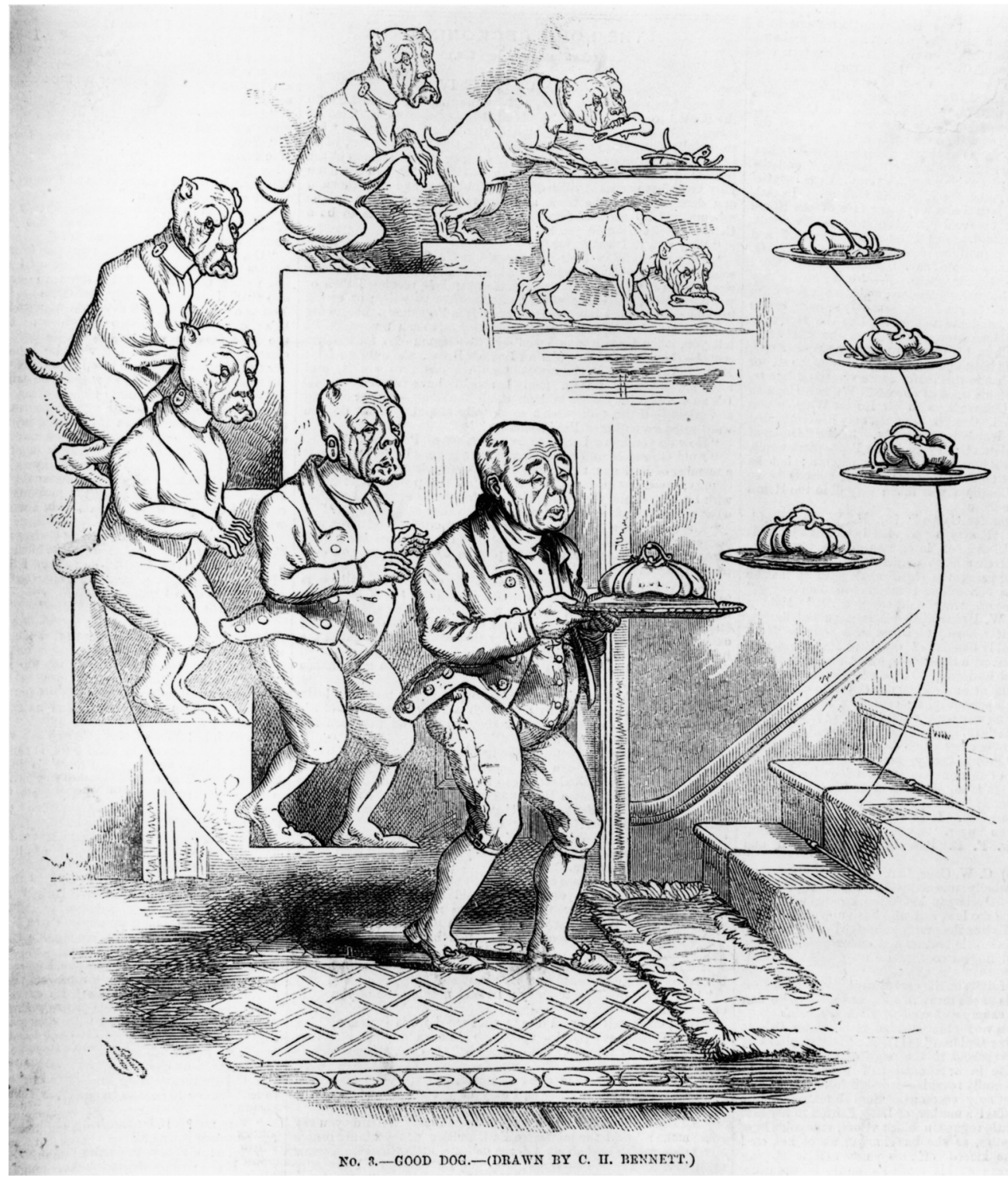

Fig. 2. A transmutationary cartoon from a set of twelve by the artist Charles Bennett, 1863. The dog with its bone, in the upper right, becomes transformed by stages into a waiter bearing a silver salver of food. The visual motif of a circle of development was common after the Origin of Species was published. Wood engraving from the Illustrated Times. Courtesy of the Wellcome Library London. 


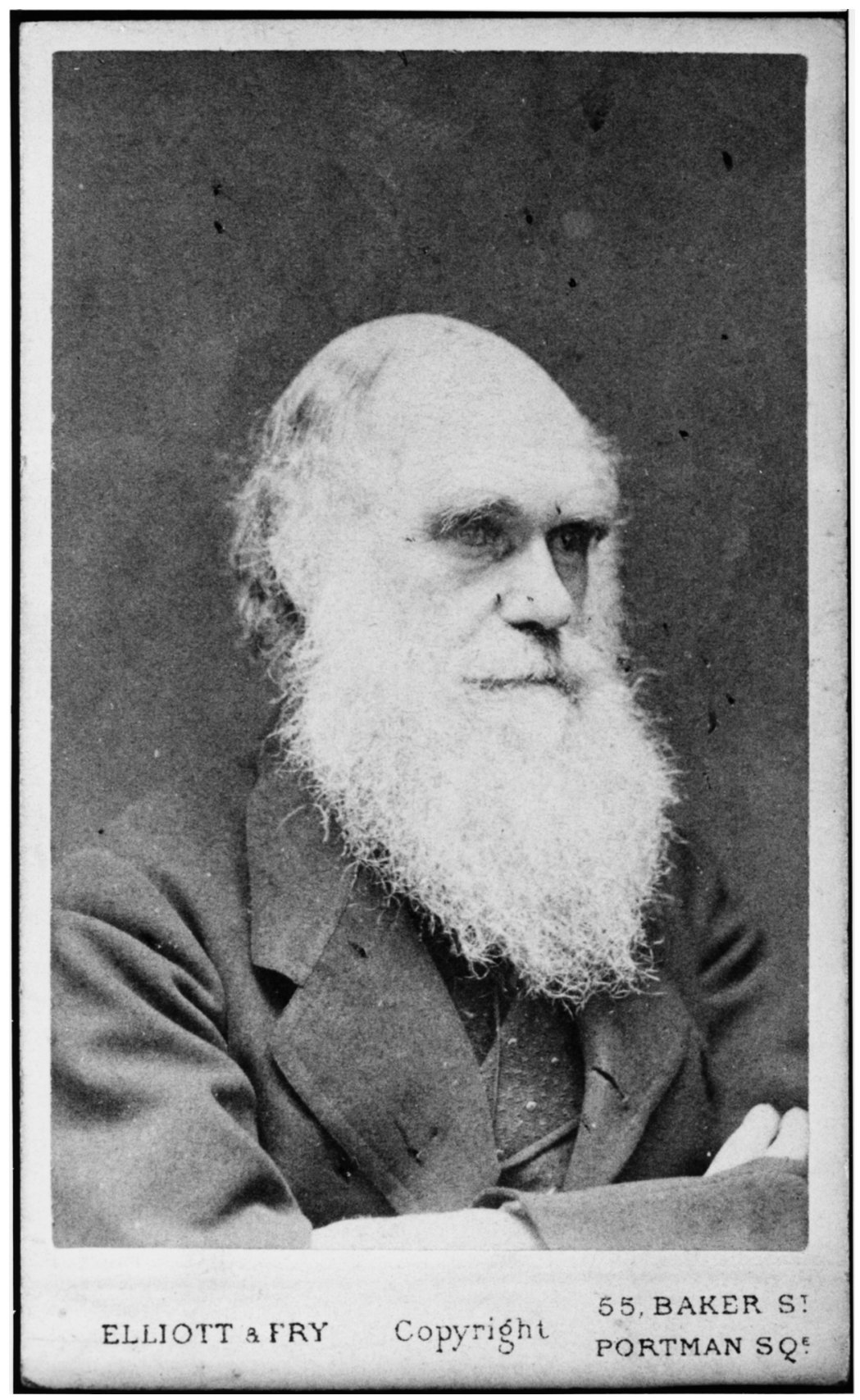

Fig. 3. A carte-de-viste of Darwin issued in the 1870 s by the London firm of photographers, Elliott and Fry. Darwin used to send his correspondents copies of this and other photographic portraits, sometimes signing them across the bottom as an autograph. Courtesy of the Wellcome Library London. 


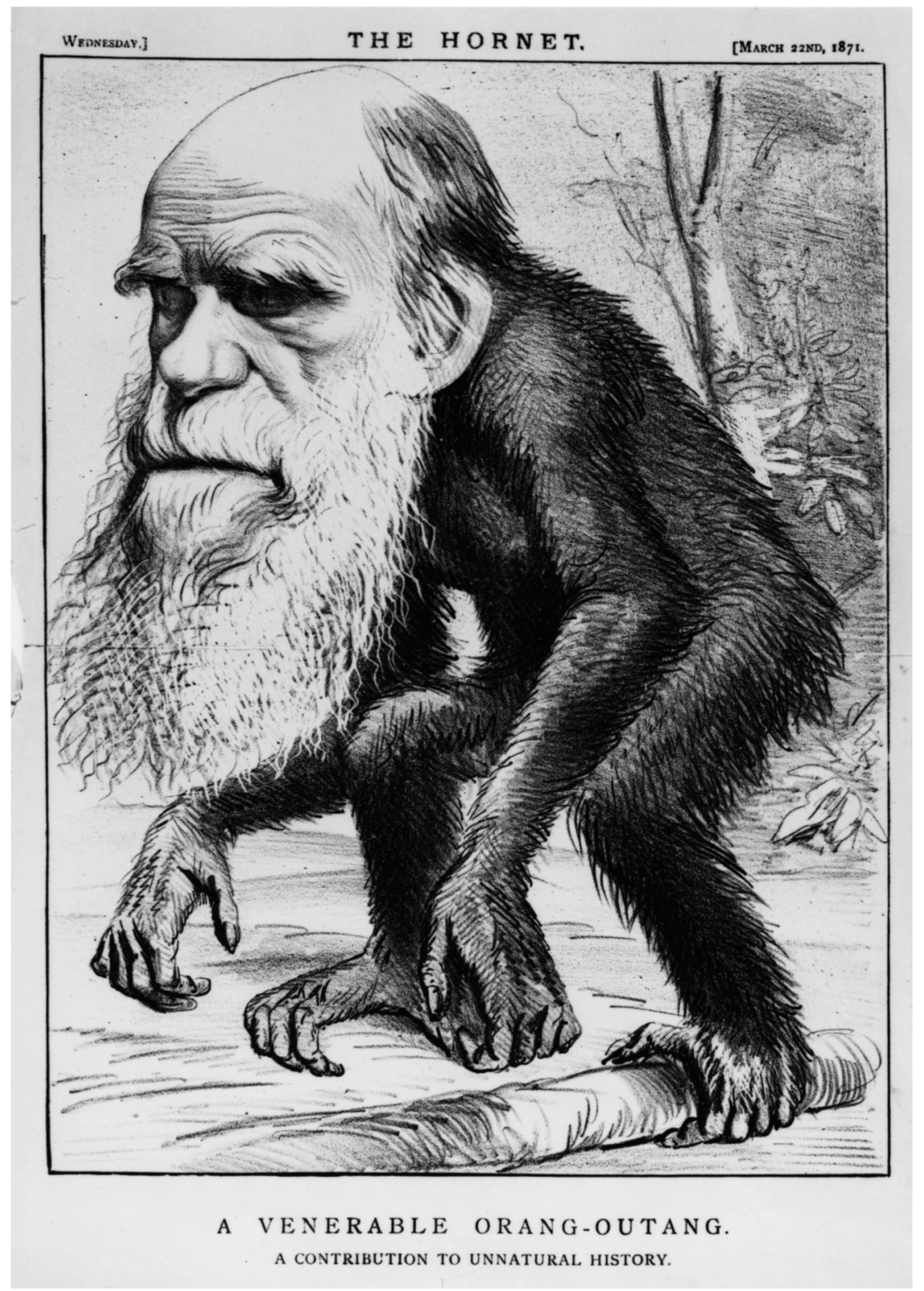

Fig. 4. "A venerable orang-outang. A contribution to unnatural history" from The Hornet, 22 March 1871. The representation of Darwin-as-ape contributed to the identification of his public persona with the idea of evolution. Author's collection. 
Shapin's Boyle or Shortland's Hugh Miller (Shapin 1991; Shortland 1996). ${ }^{22}$ To be sure, Darwin did not manipulate his image as obviously as someone like Isambard Kingdom Brunel, posing for iconic photographs in front of the anchor chains of SS Great Eastern, nor was he as overtly propagandist as Queen Victoria or William Ewart Gladstone (Vaughn 1991; Homans 1999). Darwin's points of contact with his public were subtle and, as far as we can judge, probably true to his own sense of himself. His public image was therefore not a totally manufactured one. Certainly, if there was a mask, the mask looked something like him. Nonetheless, his audiences needed to be properly primed. In an era in which the concept of a "scientific celebrity" was only gradually emerging, audiences for science were coming to know what to demand, what to expect. Darwin's personal interactions with the people who visited him therefore tended to confirm expectations that had been carefully disseminated by Darwin and his friends - that he was sick, reclusive, modest, and genial. His public appearances at carefully spaced intervals also confirmed expectations, although these expectations were surely different in that the modality of royalty, with handshakes and smiles, was preferred. Visual images such as caricatures generated and reinforced public opinion. Darwin's chosen form of contact with the public therefore contributed in a material manner to the rise in his image as a reclusive gentlemanscientist and author of the theory of evolution.

\section{References}

Altick, R. D. 1997. Punch: The Lively Youth of a British Institution, 1841-1851. Columbus: Ohio State University Press.

Am, P. A. and C. A. Elliott, eds. 1999. "Commemorative Practices in Science. Historical Perspectives on the Politics of Collective Memory." Osiris 14:1-383.

Avner, Ben-Amos. 2000. Funerals, Politics and Memory in Modern France 1789-1996. Oxford: Oxford University Press.

Baker, John F. 1996. "The Rise of the Celebrity Author." In The Professions of Authorship: Essays in Honour of M. J. Bruccoli, edited by Richard Layman and Joel Myerson, 41-43. Columbia: University of South Carolina Press.

Bennett, Charles H. 1872. Character Sketches, Development Drawings and Original Pictures of Wit and Humour. London.

Bernays, E. L. 1928. "Manipulating Public opinion: The Why and the How." American Journal of Sociology 33:958-71.

Bowler, P. 1988. The Non-Darwinian Revolution: Reinterpreting a Historial Myth. Baltimore: Johns Hopkins University Press.

Braudy, Leo. 1986. The Frenzy of Renown: Fame and its History. New York: Oxford University Press.

Briggs, P. M. 1991. "Laurence Sterne and Literary Celebrity in 1760." The Age of Johnson. A Scholarly Annual 4:251-80.

Browne, J. 1978. "The Charles Darwin-Joseph Hooker Correspondence: An Analysis of Manuscript Resources and their Use in Biography." Journal of the Society for the Bibliography of Natural History 8:351-66.

${ }^{22}$ For a general analysis, see Greenblatt 1980. 
Browne, J. 1981. "The Making of the Memoir of Edward Forbes." Archives of Natural History 10:205-19.

Browne, J. 1992. "Squibs and Snobs: Science in Humorous British Undergraduate Magazines Around 1830." History of Science 30:165-97.

Browne, J. 1998. "I could have retched all night: Charles Darwin and his body." In Science Incarnate: Historical Embodiments of Natural Knowledge, edited by Christopher Lawrence and Steven Shapin, 240-87. Chicago: University of Chicago Press.

Browne, J. 2002. Charles Darwin: The Power of Place. New York: Knopf.

Burkhardt, F. and S. Smith et al., eds. 1985-2001. The Correspondence of Charles Darwin. 12 vols, 1821-1864. Cambridge: Cambridge University Press.

Burkhardt, F. and S. Smith et al., eds. 1994. A Calendar of the Correspondence of Charles Darwin, 1821-1882: With supplement. Revised edition. Cambridge: Cambridge University Press.

Cantor, G. 1996. "The Scientist as Hero: Public Images of Michael Faraday." In Telling Lives in Science: Essays on Scientific Biography, edited by M. Shortland and R. Yeo, 171-193. Cambridge: Cambridge University Press.

Casteras, S. P. and L. H. Peterson. 1994. A Struggle for Fame: Victorian Women Artists and Authors. New Haven: Yale Center for British Art.

Colp, R. 1977. To Be an Invalid: The Illness of Charles Darwin. Chicago: University of Chicago Press.

Colp, R. 1982. "The Myth of the Darwin-Marx Letter." History of Political Economy 14:461-82.

Cooter, R. and S. Pumfrey. 1940. "Separate Spheres and Public Places: Reflections on the History of Science, Popularization and Science in Popular Culture." History of Science 32:237-67.

Conway, J. K. 1998. When Memory Speaks: Reflections on Autobiography. New York: Alfred Knopf.

Darwin, F., ed. 1887. The Life and Letters of Charles Darwin. 3 vols. London.

Desmond, Adrian. 1994/97. Huxley: The Devil's Disciple and Huxley: Evolution's High Priest, London: Michael Joseph.

Donald, D. 1996. The Age of Caricature: Satirical Prints in the Reign of George III. New Haven: Published for the Paul Mellon Center for Studies in British Art by Yale University Press.

Donoghue, F. 1996. The Fame Machine: Book Reviewing and Eighteenth-Century Literary Careers. Stanford: Stanford University Press.

Eco, U. 1979. The Role of the Reader: Explorations in the Semiotics of Texts. Bloomington: Indiana University Press.

Edelman, B. 1979. Ownership of the Image: Elements of a Marxist Theory of Law. Translated by Elizabeth Kingdom. London: Routledge and Kegan Paul.

Ellegard, A. 1990. Darwin and the General Reader: The Reception of Darwin's Theory of Evolution in the British Periodical Press, 1859-1872. Reprint, with a new foreword by David L. Hull. Chicago: University of Chicago Press.

Emma Darwin's Diary, on loan, Darwin Archive, Cambridge University Library.

Fara, P. 1997. "The Royal Society's Portrait of Joseph Banks." Notes and Records of the Royal Society 51:199-210.

Fara, P. 1998. "Images of a Man of Science.” History Today (October): 42-49.

Fara, P. 2000a. "Faces of Genius: Images of Isaac Newton in Eighteenth-Century England." In Heroic Reputations and Exemplary Lives, edited by Geoff Cubitt and Allen Warren, 59-81. Manchester: Manchester University Press.

Fara, P. 2000b. "Isaac Newton lived here: Sites of Memory and Scientific Heritage." British Journal for the History of Science 33:407-426.

Fara, P. 2002. Newton: The Making of Genius. New York: Columbia University Press.

Feuer, Lewis. 1975. "Is the Darwin-Marx Correspondence Authentic?" Annals of Science 32:1-12.

Friedman, A. J. and C. C. Donley. 1985. Einstein as Myth and Muse. Cambridge: Cambridge University Press.

Gaines, J. 1989. "Dead Ringer: Jacqueline Onassis and the Look-Alike." South Atlantic Quarterly 88:461-86. 
Gaines, J. 1991. Contested Culture: The Image, the Voice, and the Law. Chapel Hill: University of North Carolina Press.

Gamson, J. 1994. Claims to Fame: Celebrity in Contemporary America. Berkeley: University of California Press.

Gay, Hannah. 1998. “No 'heathen's corner' here: The Failed Campaign to Memorialise Herbert Spencer in Westminster Abbey." British Journal for the History of Science 31:41-54.

George, M. D. 1959. English Political Caricature; A Study of Opinion and Propaganda. Oxford: Clarendon Press.

Giles, D. 2000. Illusions of Immortality: A Psychology of Fame and Celebrity. Basingstoke: Macmillan.

Gledhill, C., ed. 1991. Stardom: Industry of Desire. London: Routledge.

Goffman, Erving. 1990. The Presentation of Self in Everyday Life. Reprint ed. London: Penguin Books.

Goode, W. J. 1978. The Celebration of Heroes: Prestige as a Social Control System. Berkeley: University of California Press.

Greenblatt, S. 1980. Renaissance Self-Fashioning from More to Shakespeare. Chicago: University of Chicago Press.

Groeben, C., ed. 1982. Charles Darwin, 1809-1882, Anton Dohrn, 1840-1909. Correspondence. Naples: Macchiaroli.

Hall, A. R. 1966. The Abbey Scientists. London: R. and R. Nicholson.

Hamilton, P. and R. Hargreaves. 2001. The Beautiful and the Damned: The Creation of Identity in Nineteenth-Century Photography. London: National Portrait Gallery.

Harvey, J. R. 1970. Victorian Novelists and Their Illustrators. London: Sidgwick and Jackson.

Healey, E. 1986. Wives of Fame: Mary Livingstone, Jenny Marx, Emma Darwin. Sevenoaks: New English Library.

Haeckel, Ernst. 1866. Generelle Morphologie der Organismen. 2 vols. Berlin.

Heyert, E. 1979. The Glass-House Years: Victorian Portrait Photography, 1839-1870. London: Prior.

Highfield, R. and Paul Carter 1933. The Private Lives of Albert Einstein. London: Faber and Faber.

Homans, M. 1999. Royal Representations: Queen Victoria and British Culture. Chicago: Chicago University Press.

Jordanova, L. 2000a. Defining Features, Scientific and Medical Portraits 1660-2000. London: Reaktion Books.

Jordanova, L. 2000b. "Presidential Address: Remembrance of Science Past." British Journal for the History of Science 33:387-406.

Keynes, Milo. 1994. "Portraits of Dr Erasmus Darwin FRS." Notes and Records of the Royal Society 48:69-84.

La Vergata, A. 1985. “Images of Darwin: A Historiographic Overview.” In The Darwinian Heritage, edited by David Kohn, 901-972. Princeton N.J.: Princeton University Press in association with Nova Pacifica.

Lawrence, C. and Steven Shapin, eds. 1998. Science Incarnate: Historical Embodiments of Natural Knowledge. Chicago: University of Chicago Press.

Litchfield, H., ed. 1904. Emma Darwin, Wife of Charles Darwin: A Century of Family Letters. 2 vols. Cambridge: privately printed.

Machann, C. 1994. The Genre of Autobiography in Victorian Literature. Ann Arbor: University of Michigan Press.

McCook, S. 1996. "'It may be truth, but it is not evidence': Paul Du Chaillu and the Legitimation of Evidence in the Field Sciences." Osiris 11:177-197.

McLachlan, J. J. 1983. Joseph Priestley, Man of Science 1733-1804: An Iconography of a Great Yorkshireman. Braunton: Merlin Books.

Maddow, B. 1977. Faces: a Narrative History of the Portrait in Photography. Boston: Little, Brown.

Margolis, S. 1995. "The Public Life: The Discourse of Privacy in the Age of Celebrity." Arizona Quarterly 51(2):81-101. 
Marshall, D. P. 1997. Celebrity and Power: Fame in Contemporary Culture. Minneapolis: University of Minnesota Press.

Miller, L. 2000. The Bronte Myth. London: Jonathan Cape.

Monaco, J., ed. 1978. Celebrity. New York: Delta.

Moore, J. R. 1982. "Charles Darwin Lies in Westminster Abbey.” In Charles Darwin: A Commemoration, edited by R. J. Berry, 97-113. London: Linnean Society of London.

Moore, J. R. 1985. “Darwin's Genesis and Revelations.” Isis 76:570-80.

Moore, J. R. 1994. The Darwin Legend. Grand Rapids, Michigan: Baker Books.

Neve, Michael, ed. 2002. Charles Darwin Life/Recollections. Harmondsworth: Penguin Books.

Outram, D. 1978. "The Language of Natural Power: the Funeral Eloges of Georges Cuvier." History of Science 16:153-78.

Paradis, J. G. 1997. "Science and Satire in Victorian Culture." In Victorian Science in Context, edited by Bernard Lightman, 143-75. Chicago: Chicago University Press.

Peterson, Linda H. 1986. Victorian Autobiography: The Tradition of Self-Interpretation. New Haven: Yale University Press.

Porter, R. 2001. Bodies Politic: Disease, Death and Doctors in Britain, 1650-1900. London: Reaktion Books.

Price, R. 1957. A History of Punch. London: Collins.

Quennell, P. 1974. Byron the Years of Fame; Byron in Italy. London: Collins.

Reeves, W. W. 1998. Celebrity Caricature in America. New Haven: Smithsonian Institution in association with Yale University Press.

Rudwick, M. J. S. 1975. "Caricature as a Source for the History of Science: De la Beche's anti-Lyellian sketches of 1831.” Isis 66:534-60.

Rudwick, M. J. S. 1976. “The Emergence of a Visual Language for Geological Science, 1760-1840.” History of Science 14:149-95.

Schickel, R. 1985. Common Fame: The Culture of Celebrity. London: Pavilion Books.

Secord, J. A. 2001. Victorian Sensation: The Extraordinary Publication, Reception, and Secret Authorship of Vestiges of the Natural History of Creation. Chicago: University of Chicago Press.

Shapin, S. 1991. "A Scholar and a Gentleman: The Problematic Identity of the Scientific Practitioner in Early Modern England." History of Science 29:279-327.

Shapin, S. 1994. A Social History of Truth: Gentility, Credibility and Scientific Knowledge in Seventeenth Century England. Chicago: University of Chicago Press.

Shortland, M. 1996. "Bonneted Mechanic and Narrative Hero: the Self-Modelling of Hugh Miller." In Hugh Miller and the Controversies of Victorian Science, edited by M. Shortland, 14-75. Oxford: Oxford University Press.

Shortland, M. and R. Yeo, eds. 1996. Telling Lives in Science: Essays on Scientific Biography. Cambridge: Cambridge University Press.

Smocovitis, V. Betty. 1999. "The 1959 Darwin Centennial Celebration in America." Osiris $14: 274-323$.

Söderqvist, T. 2000. "Immunology à la Plutarch - Biographies of Immunologists as an Ethical Genre." In Dialogues with Selves: Historical Issues and Contemporary Debates in Immunology, edited by A.M. Moulin and A. Cambrosio, 287-301. Dordrecht: Elsevier.

Sudjic, D. 1989. Cult Heroes. New York: Norton.

Sykes, A. H. 1995. The Doctors in Vanity Fair: A Gallery of Medical Men who Appeared in Caricature between 1870 and 1914. Kendal: A.H. Sykes.

Tonkonow, L. and A. Trachtenbert. 1995. Multiple Exposure: The Group Portrait in Photography. New York: Independent Curators Incorporated.

Townsend, M. L. 1992. Forbidden Laughter: Popular Humour and the Limits of Repression in Nineteenth Century Prussia. Ann Arbor: University of Michigan Press.

Vaughn, A. 1991. Isambard Kingdom Brunel: Engineering Knight Errant. London: John Murray. 
Weschler, J. 1982. A Human Comedy: Physiognomy and Caricature in Nineteenth Century Paris. London: Thames and Hudson.

Weber, A. 1936. Tableau de la caricature médicale. Paris: Hippocrate.

Yeo, R. 1988. "Genius, Method and Morality: Images of Newton in Britain, 1760-1860." Science in Context 2:257-84. 